\title{
鋼の引張・圧縮・ねじり応力下における変態塑性挙動の実験的検討
}

\author{
引田直樹 ${ }^{* 1}$, 寒河江秀太 ${ }^{* 1}$ ， 小室裕貴 ${ }^{* 2}$ ，長岐 滋 ${ }^{* 3}$ ， 大下賢一 ${ }^{* 3}$
}

\section{Experimental Investigation of Transformation Plastic Behavior under Tension-Compression-Torsion Stress in Steel}

\author{
Naoki HIKIDA*4, Shuta SAGAE, Hiroki KOMURO, \\ Shigeru NAGAKI and Kenichi OSHITA \\ *4Tokyo University of A\&T Dept. of Mechanical Systems Engineering, \\ 2-24-16 Naka-cho,Koganei,Tokyo,184-8588 Japan
}

\begin{abstract}
The elastic-plastic constitutive equation with the stress-dependent effect on phase transformation is proposed, but there are few experimental examples to verify the accuracy of the equation. Therefore, the transformation induced plasticity (TRIP) strain during pealrite reaction of S45C was measured when the hollow specimen was subjected to tension-compression-torsion uniaxial stress. TRIP strain was identified from experimental results, which are reproducible results about torsional strain. In the case of axial strain, some results had variability under same stress condition. Then we found that the constitutive equation disagree with TRIP strain under tension-compression-torsion uniaxial stress.
\end{abstract}

Key Words : Tranceformation Plasticity, Phase Transformation, Tension, Compression, Torsion

\section{1. 緒言}

鋼の相変態時に応力が負荷されると変態が促進され, 変態塑性ひずみが生じることが知られている. 相変態と 応力の関係を熱処理シミュレーションに導入するため 単軸応力下における実験をもとに構成則が提案されて きたが，これが多軸応力下に適用できるかは検討を要す る. 大塚ら ${ }^{(1)}$, 長岐ら ${ }^{(2)}$ は曲げ変形による変態塑性 係数の同定を試みている. しかし, 実験が困難であるた め多軸応力下については研究報告が少なく $(3)$, 変態塑 性に関する構成則の妥当性の評価は不十分である. 本研 究では引張・圧縮・站じり応力下において, S45C 材の パーライト変態過程で生じる変態塑性ひずみを計測し, 構成則の妥当性について検討する.

\section{2. 理論}

相変態する材料の全ひずみ速度 $\dot{\varepsilon}_{i j}$ は

$$
\dot{\varepsilon}_{i j}=\dot{\varepsilon}_{i j}^{e}+\dot{\varepsilon}_{i j}^{p}+\dot{\varepsilon}_{i j}^{T}+\dot{\varepsilon}_{i j}^{p h}+\dot{\varepsilon}_{i j}^{t p}
$$

となる.ここで上添え字 $e$ は弾性, $p$ は塑性, $T$ は熱膨 張, $p h$ は変態膨張, $t p$ は変態塑性によるひずみ速度成

\footnotetext{
*1 東京農工大学大学院（T 184-8588 東京都小金井市中
} 町 2-24-16)

$* 2$ 三菱重工業株式会社

*3 正員, 東京農工大学工学研究院

Email:50012643050@st.tuat.ac.jp
分を示す. 変態塑性ひずみ速度 $\dot{\varepsilon}_{i j}^{t p}$ は Mises 型の構成 則に従うものとすれば

$$
\dot{\varepsilon}_{i j}^{t p}=3 K(1-\xi) \sigma_{i j}^{\prime} \dot{\xi}
$$

と表わされる.ここで $\sigma_{i j}^{\prime}$ は偏差応力， $\xi$ はパーライト 変態の進行を表わす新相の体積分率, $K$ は変態塑性係 数を示す. Mises 型の相当応力, 相当変態塑性ひずみ速 度をそれぞれ $\bar{\sigma}, \dot{\bar{\varepsilon}}^{t p}$ として式 (2) を整理すると

$$
\dot{\bar{\varepsilon}}^{t p}=2 K(1-\xi) \bar{\sigma} \dot{\xi}
$$

となり, 負荷応力が相変態の生じる過程で一定であると $し て$, 変態開始 $\xi=0$ から変態終了 $\xi=1$ まで積分す ると

$$
\bar{\varepsilon}^{t p}=K \bar{\sigma}
$$

の関係が得られる.この式によって変態塑性挙動が表 現されるとした場合, 多軸応力下で応力比が異なる場合 でも相当応力が等しければ，相当変態塑性ひずみは等し くなり変態塑性係数は応力比に依存しない.これについ て実験的に確かめた例は少なく, 本研究で実験的に検討 することで構成式の妥当性について検討する. 


\section{3. 実験の概要}

実験に用いた試験片を図 1 に示す。形状は外形 $12 \mathrm{~mm}$, 内径 $10 \mathrm{~mm}$ のダンベル状で, 標点間距離は $16 \mathrm{~mm}$ である. 本試料に用いた $\mathrm{S} 45 \mathrm{C}$ の化学組成を表 1 に示す.

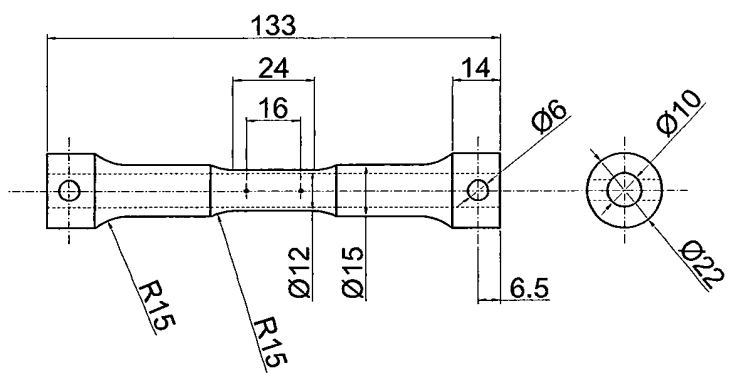

Fig.1 Specimen

Table 1. Chemical composition of $\mathrm{S} 45 \mathrm{C}$ (wt. \%)

\begin{tabular}{|c|c|c|c|c|c|c|c|}
\hline $\mathrm{C}$ & $\mathrm{Si}$ & $\mathrm{Mn}$ & $\mathrm{P}$ & $\mathrm{S}$ & $\mathrm{Cu}$ & $\mathrm{Ni}$ & $\mathrm{Cr}$ \\
\hline 0.46 & 0.16 & 0.83 & 0.14 & 0.17 & 0.04 & 0.03 & 0.15 \\
\hline
\end{tabular}

実験装置の全体図を図 2 に示す。この実験装置では 任意の引張・圧縮・ねじり荷重を負荷することが出来 る. 本研究では, S45C の相変態時に応力を負荷し，そ の際の試験片の標点間変位と温度の関係を測定する. 赤 外線加熱炉を用いて試験片を $800{ }^{\circ} \mathrm{C}$ 以上に加熱した後, 錘による一定応力負荷の下で任意の冷却速度で冷却す る. 試験片の標点間変位は, レバー式変位計の測定子を 試験片標点に押しあて，支点を介して炬外に伝えその動 きをレーザ寸法測定器で測定する. また温度の測定には 試験片に溶着した $\mathrm{K}$ 熱電対を用いる.

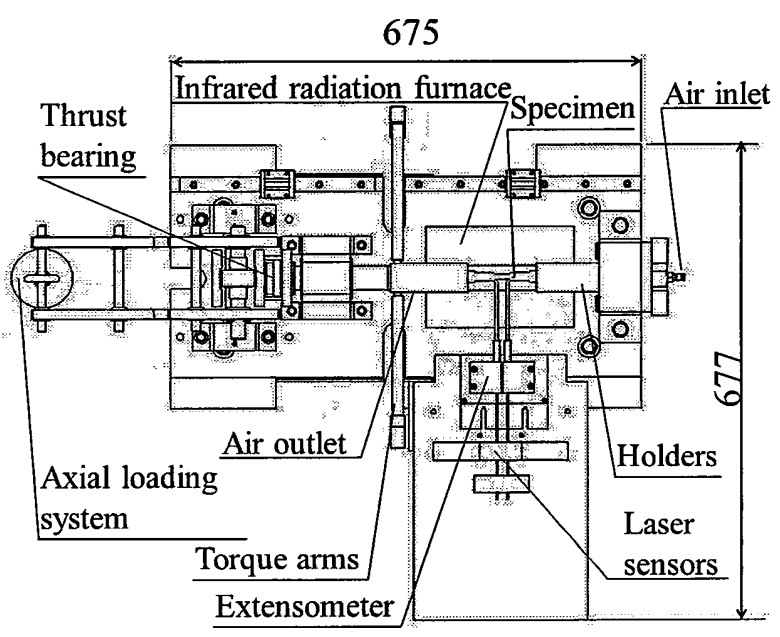

Fig.2 Top view of testing system

本実験では試験片を 5 分間で $800{ }^{\circ} \mathrm{C}$ で加熱した後,
3 分間の一定温度保持によりオーステナイト化した。 そ の後, 加熱炉の電源を切り自然冷却によりパーライト変 態させ，冷却過程の温度一ひずみ線図を取得した.

図 3 は実験に用いた試料と成分の近い材料の CCT 線図 (4)に，実験の泠却経路を重ねたものである．応力 条件を図 4 に示寸．無負荷とミーゼス型の相当応力が $12.0 \mathrm{MPa}, 24.0 \mathrm{MPa}$ の 7 条件で行った. 無負荷では 5 回, 単軸引張・単軸圧縮では 3 回, 単軸放じりでは 2 回 ずつ計測した.

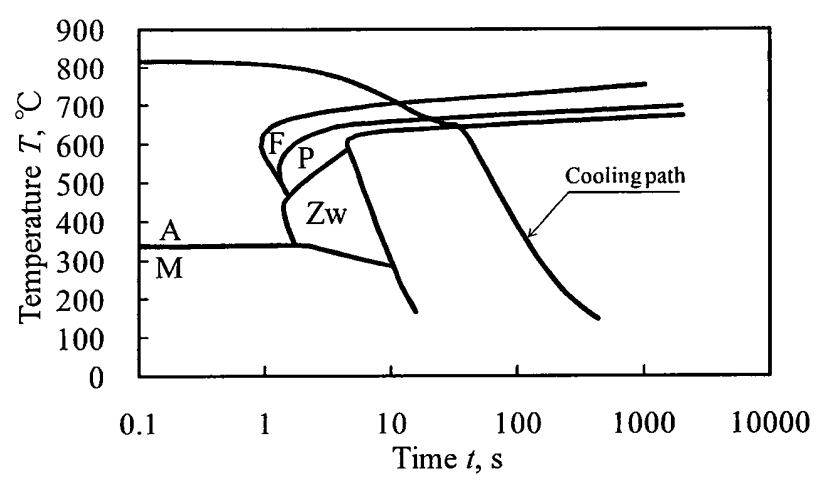

Fig.3 CCT diagram

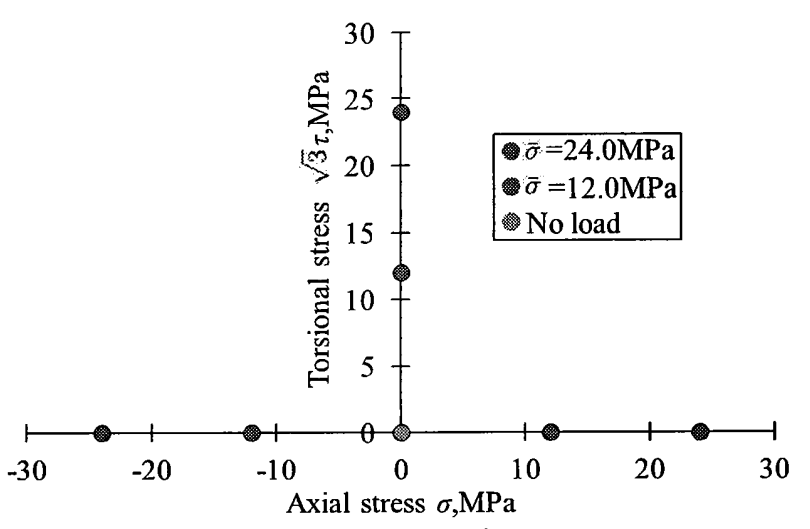

Fig.4 Stress condition

\section{4. 実験結果}

実験結果の例を図 5 と図 6 に示す. 図 5 は冷却過程 の軸方向の温度 - ひずみ線図である. 冷却開始からパー ライト変態点までは温度の低下による熱収縮で軸方向 ひずみは減少し, $670{ }^{\circ} \mathrm{C}$ 付近のパーライト変態点での変 態膨張及び応力の増加に伴う変態塑性ひずみ量の増加 を確認できる. 変態終了後は熱収縮により再びひずみ は減少していく. 図 6 は冷却過程のねじり方向の温度 - ひずみ線図である. 冷却開始からパーライト変態点ま では体積変化のみのためせん断ひずみは変化せず， 670 ${ }^{\circ} \mathrm{C}$ 付近のパーライト変態点で応力の増加に伴う変態塑 性ひずみ量の増加を確認できる. 変態終了後は体積変化 のみのためせん断ひずみは変化しない. 


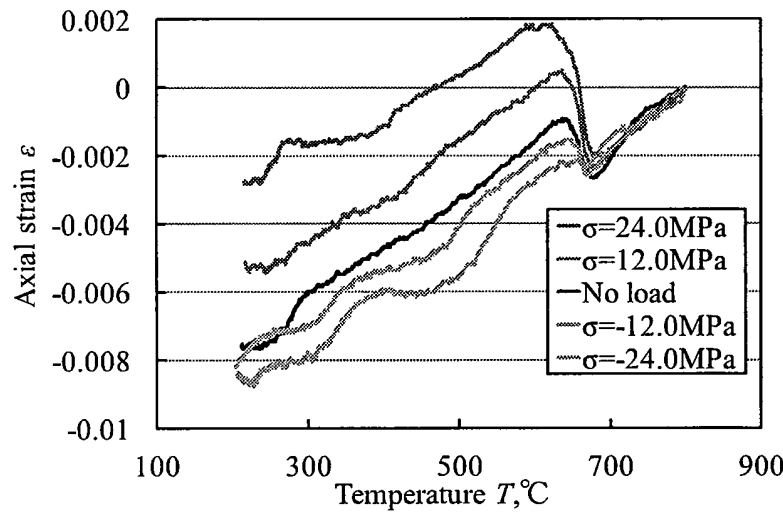

Fig.5 Temperature-Axial strain diagram

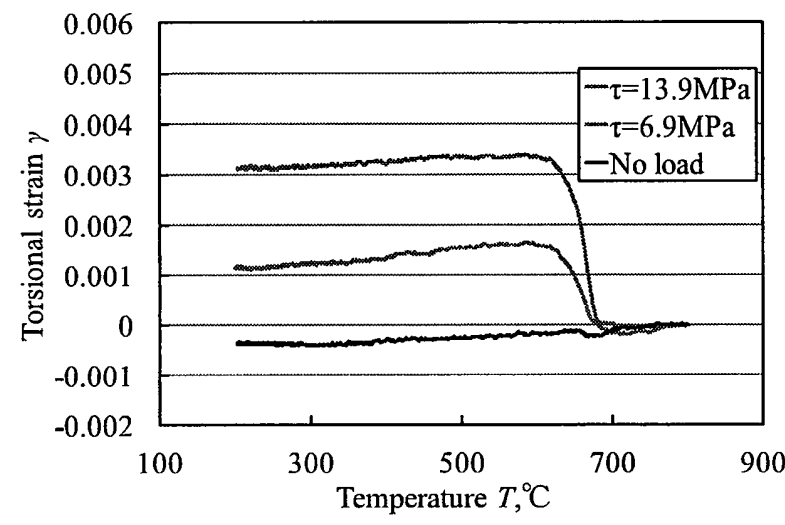

Fig.6 Temperature-Torsional strain diagram

\section{5. 考察}

パーライト変態で生じたひずみから無負荷状態で生 じたひずみを差し引くことで変態塑性ひずみを算出し た. 単軸引張, 単軸圧縮, 単軸ねじり応力の負荷方向ご とに相当応力と相当変態塑性ひずみの関係をまとめた ものが図 7 である. プロットした点は同一の応力条件 での実験值の平均值で，最大值と最小值をエラーバーで 示している. 図 7 より軸方向ひずみの測定結果のばら つきが大きいことが確認できる. また，それぞれの近似 直線の傾きが変態塑性係数となる. それぞれの負荷方向 における変態塑性係数を表 2 に示す。これから負荷方 向により変態塑性係数が異なることがわかる. 本研究で 変態塑性挙動が負荷方向に依存することを確認した.

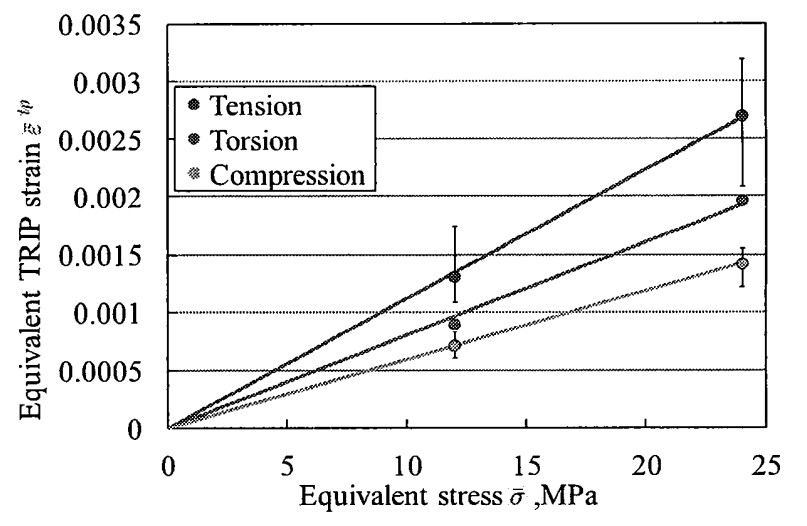

Fig.7 Equivalent stress-Equivalent TRIP strain diagram

Table 2. TRIP coefficient $K$

\begin{tabular}{|c||c|c|c|}
\hline & Tension & Torsion & Compression \\
\hline$K\left(10^{-5} \mathrm{MPa}^{-1}\right)$ & 11.2 & 8.06 & 5.94 \\
\hline
\end{tabular}

\section{6. 結言}

構成式の妥当性を検討するために引張・圧縮・ねじ り単軸応力下の変態塑性挙動を計測した. 図 7 から変 態塑性挙動が負荷方向に依存することを確認した. しか し，軸方向のひずみの測定結果のばらつきが大きいの で,この点については改善が必要だと言える. 今後は引 張・ねじり，圧縮・ねじり二軸応力下で実験を行い，構 成式について検討する.

\section{参考文献}

(1) Otsuka,T., Inoue,T., Identification of Transformation Plasticity Coefficient by Four-Point Bending Tests and Some Data under Pearlite Transformation, Journal of the Society of Materials Science,Japan, Vol.52, No.10 (1996), pp.1198-1203.

(2) Nagaki,S., Asaoka,S., Morozumi,K., Ohshita,K., Determination of Coefficient for Transformation Plasticity in Terms of Three Point Bending System, Transactions of the Japan Society of Mechanical Engineers,Series $A$, Vol.69, No.684 (2003), pp.1230-1235.

(3) Coret,M., calloch,S., Combescure,A., Experimental study of the phase transformation plasticity of 16MND5 low carbon steel under multiaxial loading, International Journal of plasticity, Vol.18, No.12 (2002), pp.1707-1727.

(4) The Japan Institute of Metals and Materials, Metal Data Book, (2004), pp.475, Maruzen. 